\title{
QUEEN'S
QNEIVERSITY
BELFAST
}

\section{"A la frontière de deux mondes": Spatial Perspectives on Mortality in Modern Physician Thanatographies}

Wilson, S. (2021). "A la frontière de deux mondes": Spatial Perspectives on Mortality in Modern Physician Thanatographies. L'Esprit Créateur, 61(1), 54-67. https://muse.jhu.edu/article/786629

\section{Published in: \\ L'Esprit Créateur}

\section{Document Version:}

Peer reviewed version

Queen's University Belfast - Research Portal:

Link to publication record in Queen's University Belfast Research Portal

\section{Publisher rights}

Copyright 2021 Johns Hopkins University Press

This work is made available online in accordance with the publisher's policies. Please refer to any applicable terms of use of the publisher.

\section{General rights}

Copyright for the publications made accessible via the Queen's University Belfast Research Portal is retained by the author(s) and / or other copyright owners and it is a condition of accessing these publications that users recognise and abide by the legal requirements associated with these rights.

Take down policy

The Research Portal is Queen's institutional repository that provides access to Queen's research output. Every effort has been made to ensure that content in the Research Portal does not infringe any person's rights, or applicable UK laws. If you discover content in the Research Portal that you believe breaches copyright or violates any law, please contact openaccess@qub.ac.uk. 


\section{Steven Wilson}

In a recently published series of témoignages on death by leading French artists and personnalités, Jean-Christophe Rufin, a clinician, writer, and one-time French ambassador to Senegal, declares that "La mort est consubstantielle à mon métier. On est en contact avec les cadavres. [...] On s'habitue." Rufin's point - made in the reference to contact with "les cadavres" rather than "les corps," still less "les patients" - is that clinicians who work in modern medicine have become desensitized to death. This suggestion is reinforced by consultant gastroenterologist Seamus O’Mahony in his reflection on Western attitudes to mortality. With specific reference to what he terms the "immunity" of the medical profession, O’Mahony writes, "although we see it every day, doctors do not think very much about death and dying."2 Rufin and O'Mahony, in their observations, remind us that the distinctive roles allocated to "doctor" and "patient" in modern medicine ensure that clear subjectivities are enforced to each. Professional barriers must be maintained, not least as a protective measure to ensure the doctor's emotional protection and wellbeing. "Le rôle du médecin," Pascal Hammel, of Paris's Hôpital Beaujon, reminds us, “est d'accompagner la souffrance avec empathie, en gardant une distance." "But what happens when this clearly defined "role" is challenged by the onset of a serious illness? What shifts in power, status, and subjectivity occur when the doctor becomes the patient and is forced to confront his or her own mortality? And what do physician accounts of dying, written from a rare perspective, reveal about our common inexorable destiny?

There is a rich French tradition of those with a medical background turning their attention to the writing of literature: dating back to Rabelais, more modern examples of such 
trajectories include Louis-Ferdinand Céline and Prix Goncourt laureate Georges Duhamel. The 2018 volume Médecins-écrivains français et francophones is the most extensive study to date on medics who exchange surgical instruments for the pen, and focuses on four themes related to medical and scientific influence in French physician writing: "les motivations, les transferts, les contaminations et les confrontations interculturelles." ${ }^{4}$ Unlike the essays contained in Pröll, Lüsebrink, and Madry's book, this article turns its attention to the introspective gaze of doctors who pick up the pen in order to articulate their perspective on dying and death. As Anne Carol has noted in her extensive study of "Les médecins et la mort," we have witnessed a process whereby, since the nineteenth century, "le médecin interv[ient] de plus en plus souvent autour du mourant, du mourir et du mort." ${ }^{, 5}$ Yet the present article considers the insights afforded by doctors who do not merely "intervenir [...] autour du mourant," but become the "mourant," contemplating and writing about dying from the very the hospital bed from which they had sought to distance themselves all their professional lives.

In the context of the contemporary upsurge of interest in this subject, especially in the anglophone world through best-selling memoirs such as Paul Kalanithi's 2016 When Breath Becomes Air, this article examines what the language used in French physician memoirs contributes to our conceptualization, articulation, and understanding of dying and death. It turns to one of the first narratives penned by a doctor-turned-patient during the period that witnessed the "medicalization of death," by René Allendy, who is given only the briefest of references in Médecins-écrivains français et francophones. The purpose of this analysis is to examine the spatial perspectives, and specifically the language of thresholds, used by the physician-turned-pathographer to relate his medical experience, contemplation of death, and change in identity from doctor to patient-writer. It will do so by offering a reading of Allendy's text alongside an autopathography by Hammel, a physician who survived a cancer 
diagnosis, and in conjunction with Kalanithi's text. In this way, the aim of this study is twofold: to develop recent consideration of the connections between place, space, and time in exploring the 'worlding' of health, healing, and well-being, begun in a special issue on the neglected theme of social and cultural geographies in the medical humanities, but that concentrated solely on non-clinical settings; ${ }^{6}$ and to evaluate the broader implications of the language of dying and death by the médecin-écrivain for a more collective understanding, one that bridges the scientific and literary imagination, of the foreboding liminal space where life gives way to death.

\section{Threshold of life}

In his 2014 memoir Being Mortal, American surgeon and writer Atul Gawande reflects on the ways in which modern medical practice and technology have doggedly combined to sustain organs and delay the moment of death. As such, he suggests, the art of dying well, the ars moriendi that developed in response to the Black Death of the late Middle Ages, has almost completely given way to a preoccupation with preserving the body for as long as possible, even beyond its natural end point. Gawande articulates the cultural impulse to defer death as a failure to embrace limits:

Being mortal is about the struggle to cope with the constraints of our biology, with the limits set by genes and cells and flesh and bone. Medical science has given us remarkable power to push against these limits, and the potential value of this power was a central reason I became a doctor. But again and again, I have seen the damage we do when we fail to acknowledge that such power is finite and always will be. ${ }^{7}$ 
"If to be human is to be limited," Gawande contends, "then the role of caring professions and institutions - from surgeons and nursing homes - ought to be aiding people in their struggle with those limits" (Gawande 260). To an extent, of course, all illness experiences, whether mild or potentially mortal, force the patient to confront the body's limits and the limits of life. These limits are often represented in spatial language. As Susan Sontag famously declared, every illness experience takes us to a border: "Everyone who is born holds dual citizenship, in the kingdom of the well and in the kingdom of the sick. Although we all prefer to use only the good passport, sooner or later each of us is obliged, at least for a spell, to identify ourselves as citizens of that other place."8 Sontag's suggestion prompts two points of reflection that are pertinent to this study. First, unlike illness in the generic singular, a specifically terminal (or potentially terminal) diagnosis obliges the patient to confront not merely the spaces between wellbeing and illness, but the borders - the very limits - of existence; for terminally ill patients, the incontrovertible reality is that the journey to "that other place" will not merely be "for a spell." Second, extending Sontag's metaphor of the passport, in any departure to what Heidegger would term the "Unheimlich," the primordially estranged state in which we are alienated from our world, and which encompasses the fear, anxiety, and social isolation that illness produces, we live not simply in the "kingdom of the sick," but in the cultural geography of exile, of not belonging. ${ }^{9}$

Rogers Brubaker, in his article on “The 'Diaspora' Diaspora," has traced the dispersion of the meaning of the term in semantic, conceptual, and disciplinary space. Brubaker proposes that the paradigm of diaspora be now considered "not in substantialist terms as a bounded entity, but rather as an idiom, a stance, a claim" that provides "a way of formulating the identities [...] of a population."10 Anoushka Sinha's recent study of Camus's La peste draws on Brubaker's observations and offers a compelling argument for extending the notion of diaspora to encompass the temporal displacement, social estrangement, and 
community exile experienced by the citizens of Oran who are affected by the plague. Sinha posits that disease engenders a diasporic experience in the townsfolk of Oran, isolating them from their loved ones, while forcing them to negotiate "a state of upheaval from the familiar to the uncertain that opens up the question of where boundaries lie and what self and identity can mean" (Sinha 90). For Sinha, La peste can thus be read as an example of diasporic literature. I want to suggest here that thanatography in general, and physician thanatography in particular, all of which dwell heavily on "where boundaries lie," might also be read within the conceptual parameters of diasporic literature. This is notably the case because dying is often articulated in the language of spatial dislocation in thanatography, recalling early (especially Jewish) discussions of diaspora that were firmly rooted in the idea of the "homeland." For physician thanatographers, the displacement in identity from consultant surgeon to dying patient takes them on a specific journey into a metaphorical wilderness that resembles the antithesis of their "homeland" state.

When a disease affecting the body is potentially fatal, the patient who journeys - to return to Sontag's language of travel - to a different land, and who comes to terms, if not necessarily adjusts, to their new horizons, occupies new terrain. Consultant oncologist Hammel, in his memoir on the treatment he received for a highly malignant lymphoma tumor, summarizes the plight of taking on such a new identity in the language of physical geography. Evoking the moment of diagnosis, Hammel imagines himself at a crossing point: “Pour représenter cet instant crucial, une métaphore me vient à l'esprit: celle du patient qui traverse un pont au-dessus d'un fleuve et se retrouve en terra incognita. [...] Au-delà du pont survient un brutal changement de paysage, de vie" (Hammel 25). ${ }^{11}$ In Hammel's use of the present tense, he evokes the ongoing immediacy of a journey whose every step takes him further into a terra incognita replete with loss - of perspectives, of experiences, of people, in short, of all that is familiar and comforting. In his use of the adjective "brutal" to characterize 
this sudden "changement de paysage, de vie," Hammel also signals his passivity, as someone whose new reality has been aggressively forced upon him, whose "passport" (again, borrowing from Sontag) has been forced into his hands. Even so, the moment of diagnosis, laden with emotion, offers Hammel an opportunity for connection, for in his use of the generic singular to describe "[le] patient qui traverse un pont," he identifies with other individuals - including his former patients - who have found themselves in a similar position to his. For the physician-turned-patient, then, the impromptu journey from médecin to malade invokes a particular shift in subjectivity: he or she crosses into new territory in terms of professional identity, while simultaneously entering the contact zone between life and death.

In physician memoirs, the liminal zone in which dying is contemplated, and possibly eventually experienced, is frequently represented in the concept of the in-between, giving expression to the disparate reality of the patient who dwells in a transitory state. In the thanatographies considered in this article, the diasporic language of boundaries borrows from the lexis of cultural geography. Hammel describes his estranged experience of illness as being akin to walking through an ominous valley. During a particularly anxious moment in his treatment for cancer, he petitions God, with whom he admits having "des relations épisodiques," and opens a chapter of his pathography with an epigraph drawn from the Psalms: “"Quand je marche dans la vallée de l'ombre de la mort, je ne crains aucun mal, car tu es avec moi"' (Hammel 117-18). This instance of biblical intertextuality provides Hammel with a language for conveying the liminal, foreboding space in which he lives with his illness. For Kalanithi, the process of transition from one of America's most renowned surgeons to cancer patient, at the age of thirty-six, is also rendered in spatialized terms more normally used to evoke geographical intermediacy. In Kalanithi's case, however, rather than a bridge to the unknown or a meandering journey through a desolate valley, his course takes the form of a disjuncture in, and interruption to, the seemingly coherent path of life. Having 
“always imagined the doctor's work as something like connecting two pieces of railroad track, allowing a smooth journey for the patient," when Kalanithi finds himself exchanging his metaphorical identity as engineer for that of hapless voyager, he turns to language that would not be out of place in a travelogue to express his perplexity: "I hadn't expected the prospect of facing my own mortality to be so disorientating, so dislocating," he admits. ${ }^{12}$

René Allendy, renowned clinician, homeopath, and one of the pioneers of psychoanalysis in France, provides a further illustration of the geographical language used to capture the space in which dying takes place, along with the attendant challenges posed to identity and (self-)awareness when the doctor becomes the critically ill patient. Even if Allendy's work has received scant critical attention, it occupies an important place in French physician thanatology, “une tradition inaugurée," Pröll argues, by Allendy’s Journal d'un médecin malade (Pröll 21). In his 1944 memoir, Allendy declares, though more dramatically and explicitly than Hammel and Kalanithi, that he finds himself at a threshold space, "au seuil de la mort." 13 The conceptual border at which Allendy locates himself, demarcated as the very limits of life, is described as an ambiguous, shapeless, purposeless, listless zone - a liminal space in which dying takes place:

Je me vois à la frontière de deux mondes. La vie des hommes où j'étais ces jours derniers avec le goût des repas, les problèmes professionnels, l'anxiété sur le sort du monde; et l'autre monde fait de fumées sombres un peu lourdes, un peu informes, sans couleur, sans relief, sans joie ni tristesse, de fumées qui sont comme la dissolution de tout ce qui a existé et qui n'a maintenant plus de formes solides. (Allendy 5) 
Allendy's image is striking for its visual, quasi-impressionistic qualities. Declaring himself to be at a contact zone - to extend further the conceptualization of diasporic literature, and draw on the term Mary-Louise Pratt uses in a different context to identify those "spaces where cultures meet, clash and grapple with each other"14 - Allendy possesses dual vision into two separate worlds, whose interface is rendered linguistically in the passage cited above through the use of the semi-colon. His account points us to the glaring disparity he perceives between a life ("la vie") marked by the simplicity and familiarity of routine - the lack of preposition linking the three examples adding to the sense of quotidian rhythm - and the "autre monde" in which he now finds himself, characterized by its mirror image of three negative phrases ("sans couleur, sans relief, sans joie"). On the threshold of entering a "new world" composed of vague, imprecise, abstract forms, and painted in the dark grey monotones of heavy, polluting, evaporating smoke, Allendy colors his account in such a way as to render the state of dying as a liminal space characterized by dissipation, decay, and decomposition. The grim tones of his morbidly bleak description nonetheless suggest that, while the doctor has crossed the figurative border to become the patient, he is conscious of, reflects on, and, to that extent, seeks to engage with his subjective experience of dying. In this respect, it is the "border crossing" from doctor to writer - or, more specifically, from doctor to patient-writer - that is crucial to the creation of a new identity, an identity that "bridges" the worlds of medicine and literature, and that allows for a rich, multi-dimensional meditation on the pathological and experiential aspects of dying.

Allendy's "changement de paysage, de vie" is every bit as "brutal" as Hammel's. For each of the physician-writers considered in this article, whether they convey their ordeal through the metaphor of a bridge, a border or a valley, the language of thresholds used to represent the experience of inhabiting a liminal space between distinct worlds applies not only to the interface of life and death that extends before them, but to the role-disorientation 
they experience as they negotiate their identity as doctor and patient. Like Allendy, Kalanithi conceptualizes his new standpoint as a terminal cancer patient in bifocal terms: "Once I had been diagnosed with terminal illness, I began to view the world through two perspectives; I was starting to see death as both doctor and patient" (Kalanithi 139). Hammel, for his part, expresses his new identity through a political metaphor: "Là, j'ai vraiment la double casquette, je cumule les mandats: celui du malade et du médecin” (Hammel 76). Such observations seemingly align with the study carried out by psychiatrist Robert Klitzman, who posits that "Doctors who get sick have uniquely been on both sides of the stethoscope, and possess unique double lenses." ${ }^{15}$ Klitzman's suggestion implies that the doctor-turned-patient maintains a dual identity through diagnosis, treatment, and care. Yet the physician memoirs considered in this article invite us to reflect further on this assumption, especially when the doctor becomes not only a patient, but a patient-writer. While Kalanithi agrees that his background in medicine helps him to process the data charts telling the story of his bodily condition at any given moment "and accept the limits of what the data could reveal about my prognosis," he is nonetheless unambiguous that his training and experience as a physician “didn't help me as a patient" (Kalanithi 139). Kalanithi's assertion is that, in the face of death, while his identity as doctor is never abandoned as such, it is his status as patient that nonetheless comes to the fore.

Hammel, too, underlines his human vulnerabilities in the face of illness by indicating that his perspective as patient eclipses his medical knowledge, training, and experience:

le médecin est un être humain comme les autres quand il est malade: inquiet, faillible, parfois irrationnel voire superstitieux. [...] Il est sans doute bien placé pour comprendre les choix thérapeutiques, assurément. Mais son expérience et ses connaissances génèrent des angoisses bien spécifiques à sa qualification. Elles ne le 
protègent pas non plus des aléas des traitements et des dangers de la maladie. Ni de la mort, bien sûr. (Hammel 298)

Hammel posits death as the great leveller, subordinating professional and technical competence to the common human anxieties that confront all patients, and to which medical expertise alone cannot provide reassuring answers. O’Mahoney concurs with his medical confrères on this matter. In his use of a rhetorically loaded question, he undermines any assumption that doctors might experience terminal illness differently to other people: "Medical knowledge is, or should be, a huge advantage when facing death. We know how it goes. We can decode the smooth words of the oncologist. We understand the implications of any given diagnosis. This should help - shouldn't it?' (O’Mahony 233).

In their statements, Kalanithi, Hammel, and O'Mahony introduce subtle but important nuances to Klitzman's suggestion that doctors who become ill possess "unique double lenses." This may be because of the serious nature of the disease for which they are being treated, thereby reminding us that perspectives will vary depending on the particularities of any given illness experience. The accounts examined in this article might appear at first to suggest that a potentially or almost certain terminal illness can result in an increased sense that the physician-turned-patient has exchanged the control, assurance, and authority associated with medicine for the passivity of patienthood. Thus, when admitted to hospital - a hospital he will never leave, at least alive - Allendy's first concern, recalling the stereotype of the 'heroic medic,' is that he will not be able to see his patients the next day: 'c'est vraiment une abdication, une défaite. Les rôles sont renversés," he reflects (Allendy 1). Yet the idea of a complete reversal in roles is not borne out by a close reading of the text, for Allendy is never solely a patient. As he confronts the turn of events that sees him hospitalized quite suddenly, and writes about his first night under medical care, he remarks: 
La nuit a été très pénible, j’ai retrouvé cette sensation de cœur défaillant que j'avais déjà connue il y a quelques semaines, l'impression d'avoir dans la poitrine un organe qui va cesser sa tâche, si ce n'est pas maintenant, dans quelques minutes, une promenade en bordure de l'agonie, l'impression que chaque battement est une nouvelle chance sur laquelle on ne pourra pas compter longtemps. (Allendy 1)

A close analysis of the language used in this quotation does indeed point to a "double lens" perspective on dying, but it is not one that can be reduced neatly to the duality of doctor and patient. From a biomedical standpoint, Allendy detects "cette sensation de cœur défaillant" and "dans la poitrine un organe qui va cesser sa tâche." Yet, at the same time, he describes his condition in the non-medical - and, indeed, very literary - language of a patient-writer, as someone who has embarked upon "une promenade en bordure de l'agonie." Having "abdicated" his role as medic and relinquished power over his body, Allendy takes on a new subjectivity as a writer - and, crucially, one from a medical background - who reflects from a position of medical authority on what is happening to his body. As I argue in the next section, it is this unique status as doctor-turned-patient writer that affords Allendy and the other physicians considered in this article a significant and remarkable perspective on dying.

\section{Thresholds of identity}

Klitzman, in his book that examines how doctors who become patients "trav[el] from the land of healing to that of disease," regards such individuals as "shuttling" between dual roles: "In their shuttling, these doctors illuminated the refractions between their dual roles of physician and patient - the width, depth, subdivisions, and substance of the chasm between these two 
poles" (Klitzman 8). Yet, as Kalanithi explains, "shuttling" does not help him to make sense of his condition:

Like my own patients, I had to face my mortality and try to understand what made my life worth living - and I needed [my wife's] help to do so. Torn between being a doctor and being a patient, delving into medical science and turning back to literature for answers, I struggled, while facing my own death, to rebuild my own life - or perhaps find a new one. (Kalanithi 139)

Kalanithi's statement reflects on the challenges and the possibilities of finding an identity in the face of death. In the process of coming to terms with their fate, many terminally ill patients contemplate the shifts in identity that dying brings upon them, while simultaneously attempting to process and make sense of that fate. This task is made all the more complicated in scenarios whereby the hierarchical power invested in medicine conspires to silence the patient and deny their subjectivity in the process of dying. ${ }^{16}$ Yet the impact of such actions is heightened when the patient in question is a former medic. In his thanatography, Allendy rebukes the bedside manner of "le confrère C," who displays a distinct lack of interest in the patient's situation. This lack of empathy on the part of a physician is exacerbated when he decides to defer any decision on Allendy's treatment to a colleague, rather than discuss it with the patient himself:

Encore le matin avec la tête éclatée, le corps brisé. Le Dr C... [...] a catégoriquement refusé de donner un avis sur le traitement pour ne pas empiéter sur le terrain du Professeur R.... Ainsi, [...] je suis, pour les soins, plus abandonné qu'un chien malade dans les campagnes: c'est la rançon d'être médecin. (Allendy 48) 
This dehumanizing attitude on the part of the physician reinforces medical hierarchies that result in Allendy not being treated as a competent, medically-informed patient capable of discussing his treatment, but as one who is reduced to the status of a stray animal, a creature belonging to no fixed abode. Yet the very fact that Allendy reflects on his experience and challenges it in his Journal gestures to the power of writing as an enabling act that generates a subjectivity for the médecin-écrivain who does not so much "shuttle" between identities as doctor and patient, as embrace the creative possibilities afforded by writing about dying to tie together into a coherent account some of the defining elements of his life.

Poised between life and death, "l'existence suspendue à un fil" (Allendy 155), one of Allendy's primary experiences of inhabiting the precarious space of dying is physical fatigue, to the extent that he wilfully imagines himself at the point of death on occasion: "On peut dire que si la journée du 1er mai a été une agonie, celle-ci [le 5 mai] a été une journée de mort. Il y a eu en moi comme un besoin d'anéantissement, comme une sensation de la lutte, comme une acceptation de non-être" (Allendy 165). In his reference to "la lutte" in which he visualizes himself taking part, Allendy draws on one of the common metaphors of illness, in which disease is conceptualized as an "enemy other," "invading" the defenceless body. ${ }^{17}$ But here, in its specific application to dying rather than to illness per se, Allendy reorients the allusion in such a way that death itself is seen as an attacking entity, infiltrating a vulnerable body. In this way, a second spatial configuration of dying is established, in which the perishing body is figured as a battle site. This configuration is rendered linguistically in the use of the preposition "dans" in Allendy's description of death as an object that has entered his body: “J'ai bien senti la lutte entre ce qui tient à la vie au fond de moi et l'image de la mort. [...] J'ai eu l'impression que la mort était déjà dans mes bras" (Allendy 162). Such descriptions are not formed from Allendy's medical background, but from his particularly 
traumatic military experience during the First World War. The victim of a gas attack in the Champagne region in 1915, Allendy was thought to have contracted tuberculosis and was taken out of active service as a result. Almost thirty years later, on his deathbed, his wartime trauma provides him with a language for describing his experience of dying: "Il m'arrive au cours de ces réveils d'être habité par des images de guerre. [...] [L]es grands tanks russes comme des forteresses d'acier avancent, écrasent devant eux morts et vivants dans une infâme bouillie. Je comprends que psychiquement je vibre à cette agonie” (Allendy 175).

Allendy's thanatology demonstrates a parallel "battle" to that between life and death. In the process of writing, he notes not only the pain and fatigue from which he suffers, but the fact that he is aware of what he is living through: "Je me sens une fatigue immense, surhumaine; l'idée de changer de position dans mon lit me paraît une entreprise écrasante. Chaque parcelle de mon corps est douloureuse, déchiquetée, battue. On dirait qu'à la fois, je deviens plus conscient des souffrances de mes cellules et enfoncé dans la fatigue et la douleur" (Allendy 41). This consciousness is significant because self-awareness - here enhanced by the act of writing - is, according to Stan van Hooft, connected to the idea of ownership of an experience, and thereby to subjectivity: "We are conscious, not just of the world, but also of our being conscious of the world. We are aware of being aware. Another way of putting this is to say that any experience or thought has an owner." 18 Having crossed borders of professional identity and from health to the limits of life, for the physician thanatographer seeking to write about his or her experience of critical illness, it is a sine qua non that a subjective, self-aware ownership of the space in which dying takes place must occur. In order for this to happen, physician-writers must find their own language to give expression to dying - a condition so overwhelming and/or physically draining that it can elude words. Thus, confronted with medical treatment that sees power increasingly concentrated in the figure of the physician, Allendy uses his status as physician-writer, who 
understands medicine and knows his own body, to reflect on his condition, express it in writing, and reassert his subjectivity. This reflection is particularly evident in one episode when Allendy uses the process of writing his thanatography to question the diagnosis of his physician:

Le Professeur R... est revenu me voir. Il m’a trouvé le cœur et les poumons en meilleur état et ne semble pas vouloir s'inquiéter de mes œdèmes. Il semble vraiment du fond du cœur très optimiste. Moi je trouve que ce mal commence trop à durer sans changements et à devenir chronique. Je sens ma hernie augmenter à chaque quinte de toux; depuis deux jours l'œdème gagne les bras et les mains, maintenant il est si marqué que je suis maladroit pour écrire. J'ai l'impression que cette nouvelle extension n'est pas compensée par une réduction suffisante dans d'autres endroits. Ma bronchite se réduit à une trachéite et rend ma toux plus cassante. Tout ça se traduit en angoisse profonde. (Allendy 171)

The use of the emphatic pronoun "moi" signals an assertive foregrounding of subjective experience on Allendy's part, in juxtaposition to the medical stance proffered by Le Professeur R... This opposition of patient experience to medical authority is entrenched not only by the contrasting subject pronouns used to begin sentences, but by the fact that je outnumbers $i l$ two-fold in the quotation. That the contrast in perspectives is rendered through verbs of sensation ("Il m'a trouvé" / "je trouve que," "Il semble..." / "Je sens," and "J'ai l'impression que") suggests that the patient-writer values self-knowledge as a crucial component of medical diagnosis. In the act of writing, with its requirement for examination, reflection, and the crafting of language to render the otherwise bewildering experience of 
dying, Allendy seizes an opportunity to embrace a new, enabling subjective space in which self-awareness is made possible.

It is not the "dual lens" of the physician-turned-patient that provides the unique perspective on dying in the accounts explored in this article; instead, it is the abridged identity of the médecin-écrivain that generates a new subjectivity in which important insights into mortality are garnered. To be conscious of and 'own' his experience, Kalanithi explains the importance he attaches to the search for words that will express his condition. "Lost in a featureless wasteland of my own mortality, and finding no traction in the reams of scientific studies, intracellular molecular pathways, and endless curves of survival statistics" (Kalanithi 148), he describes how he turns to literary works, by anyone who has ever written about mortality, in order to gain access to a language with which to convey his plight. Having lost his professional identity as medic, he then finds purpose in the "translation" of his direct experience into language, which grants him a new subjectivity in which he "defines" himself:

I was searching for a vocabulary with which to make sense of death, to find a way to begin defining myself and inching forward again. The privilege of direct experience had led me away from literary and academic work, yet now I felt that to understand my own direct experiences, I would have to translate them back into language. Hemingway described his process in similar terms: acquiring rich experiences, then retreating to cogitate and write about them. I needed words to go forward. (Kalanithi 148-49)

As with Hammel's borrowing from the poetic language of the Psalms, Kalanithi draws attention to textual influence in the process of "translating" experience into words. Allendy also refers back to books he read in a bid to give expression to his condition, but in his case 
he makes reference to medical texts: “[M]a sensation se précise. C'est comme si la tête était soumise à une pression intérieure proche du point d'éclatement. Est-ce cela la céphalée hypertensive dont parlent les livres de médecins?" (Allendy 20). Yet Allendy's question symbolizes the growing detachment he experiences between his lived experience of dying and the scientific characterizations of illness he once read about in textbooks.

While Allendy affirms that "On ne sent jamais tant la faiblesse de la médecine que quand on est à la fois malade et médecin" (Allendy 119), his text is not merely a lament against the medicalization of death. Instead, writing about dying offers Allendy the potential to bring to bear knowledge and experience, and to record these in a language that transcends literature or medicine as distinct categories. Journal d'un médecin malade, written by "celui qui ne peut plus se penser ni comme médecin sachant ni comme malade confiant" (Danou 184), thus unveils a rich perspective on mortality from a vantage point where medicine meets literature. As Danou suggests, Allendy’s text offers “une réflexion sur la médecine à partir d'une expérience pratique enrichie par la polyphonie du texte littéraire" (Danou 185). In the specific context of writing about dying, such "enrichment" takes place, I have suggested in this article, at its very own contact zone, at which the challenges of representing the transitory state of dying are articulated in a textual space where life experience, medical expertise, and the literary imagination meet, and whence a considered, multifaceted reflection on mortality emerges.

\section{Conclusion}

In the first part of his influential 1959 Rede Lecture, C.P. Snow - "by training" a scientist, "by vocation" a writer - lamented that there seems "to be no place" where the two cultures meet. ${ }^{19}$ Much has changed since then, of course, notably the development of the medical humanities as a scholarly field facilitating the elimination of disciplinary barriers. Snow's 
lecture was also delivered well before the modern phenomenon that is the bestseller physician memoir, in which the meeting of cultures is a defining characteristic. Allendy's thanatography, published before Snow's lecture, is, in many ways, pioneering. When read alongside more contemporary physician thanatographies, it points to the role played by the literary imagination in generating a richly textured language for dying that combines a perceptiveness to experience as much as to the medical condition of the body. Such language tends to accentuate the lexicon of meeting places - the bridge, the border, the battlefield and is born of a complex intersection of identities: doctor-turned-patient, patient-writer, médecin-écrivain. Physician thanatology, then, is uniquely located on boundaries, where one state meets another. Limits, it declares, are what define dying. Yet it also encourages the reader to embrace these limits, because they do not signal finite endpoints as such; instead, limits offer connection, possibly with what lies beyond, but certainly with everyone who will one day have to confront them. As Gawande puts it, limits present the tantalizing prospect that a link will be forged in the "chain of history": "The only way death is not meaningless is to see yourself as part of something greater: a family, a community, a society. If you don't, mortality is only a horror" (Gawande 127). By bringing us on a journey to the limits of life, and to a place where medicine meets the subjective imagination, physician thanatologies not only propel a demedicalization of death, but invite their readers - doctors and/or future patients - to a literary place of humanistic connection at which we too can contemplate, and find a language to articulate, understand, and perhaps even come to terms with the ultimate taboo that is death.

Queen's University Belfast 
${ }^{1}$ Catherine Ceylac, À la vie à la mort (Paris: Flammarion, 2018), 202.

${ }^{2}$ Seamus O’Mahony, The Way We Die Now (London: Head of Zeus, 2016), 12.

${ }^{3}$ Pascal Hammel, Guérir et mieux soigner: Un médecin à l'école de sa maladie (Paris: Fayard, 2008), 116.

${ }^{4}$ Julia Pröll, “Aller-retour entre le bistouri et la plume: contextes - questionnements perspectives," Médecins-écrivains français et francophones: Imaginaires - poétiques perspectives interculturelles et transdisciplinaires, Julia Pröll, Hans-Jürgen Lüsebrink, and Henning Madry, eds. (Würzburg: Königshausen \& Neumann, 2018), 17.

${ }^{5}$ Anne Carol, Les médecins et la mort, XIXe-XXe siècle (Paris: Flammarion, 2004), 14.

${ }^{6}$ Sarah Atkinson, Ronan Foley, and Hester Parr, "Introduction: Spatial Perspectives and Medical Humanities," Journal of Medical Humanities, 36:1 (2015): 1-4.

${ }^{7}$ Atul Gawande, Being Mortal: Illness, Medicine and What Matters in the End (2014)

(London: Wellcome Collection, 2015), 259.

${ }^{8}$ Susan Sontag, Illness as Metaphor and Aids and its Metaphors (New York: Penguin, 1991), 3.

${ }^{9}$ Heidegger suggests that, like death, we cover the felt sense of not-being-at-home by involving ourselves in always deeper illusions of familiarity. Martin Heidegger, Being and Time, John Macquarrie and Edward Robinson, trans. (New York: Harper and Row, 1962), 203-55.

${ }^{10}$ Rogers Brubaker, “The 'Diaspora' Diaspora,” Ethnic and Racial Studies, 28:1 (2006): 12. Cited in Anoushka Sinha, "“Circles of Separation and Solidarity”: Dimensions of Diasporic Experience in The Plague," The Health Humanities and Camus's "The Plague," Woods Nash, ed. (Kent, OH: Kent State U P, 2019), 97.

${ }^{11}$ Later in the text, when reflecting on his successful medical treatment and return to work, Hammel uses another spatialized metaphor to describe the 'return journey': "Mais il est grand 
temps de repasser la barrière malade-soignant et de retourner m'occuper de ceux qui ont besoin de mes compétences" (Hammel 271).

${ }^{12}$ Paul Kalanithi, When Breath Becomes Air (London: Vintage, 2016), 148.

${ }^{13}$ René Allendy, Journal d'un médecin malade, ou six mois de lutte contre la mort (Paris:

Editions Denoël, 1944), 6.

${ }^{14}$ Mary Louise Pratt, “Arts of the Contact Zone,” Profession (1991): 34.

${ }^{15}$ Robert Klitzman, When Doctors Become Patients (Oxford: Oxford U P, 2008), 4.

${ }^{16}$ As Arthur W. Franks puts it, patients "surrender their bodies to medicine," which conspires to "take away" their voice. The Wounded Storyteller: Body, Illness and Ethics (Chicago: U of Chicago P, 1995), 7, 16.

${ }^{17}$ See Sontag 65-67.

${ }^{18}$ Stan van Hooft, Life, Death, and Subjectivity: Moral Sources in Bioethics (Amsterdam: Rodopi, 2004), 29.

${ }^{19}$ C.P. Snow, The Rede Lecture, 1959 (Cambridge: Cambridge U P, 1959), 1. 